\title{
Chromosome mapping of a Tcl-like transposon in species of the catfish Ancistrus
}

\author{
Keteryne Rodrigues da Silva', Sandra Mariotto², Liano Centofante ${ }^{3}$, \\ Patricia Pasquali Parise-Maltempi ${ }^{1}$
}

I Laboratório de Citogenética Animal - Universidade Estadual Paulista "Júlio de Mesquita Filho" Campus de Rio Claro-Av 24A, 1515 Jardim Bela Vista-13600-000-Rio Claro/SP, Brasil 2 Instituto Federal de Ciências e Tecnologia do Mato Grosso, campus de Cuiabá - Bela Vista, MT, Brasil 3 Instituto de Biociências, UFMT Universidade Federal de Mato Grosso, Cuiabá, MT, Brasil

Corresponding author: Patricia Pasquali Parise-Maltempi (parise@rc.unesp.br)

Academic editor: E. Krysanov | Received 15 September 2016 | Accepted 28 November 2016 | Published 20 January 2017

http://zoobank.org/9B525AB3-8A4E-4429-9215-93CA8D265A27

Citation: da Silva KR, Mariotto S, Centofante L, Parise-Maltempi PP (2017) Chromosome mapping of a Tc1-like transposon in species of the catfish Ancistrus. Comparative Cytogenetics 11(1): 65-79. https://doi.org/10.3897/ CompCytogen.v11i1.10519

\begin{abstract}
The Tc1 mariner element is widely distributed among organisms and have been already described in different species of fish. The genus Ancistrus (Kner, 1854) has 68 nominal species and is part of an interesting taxonomic and cytogenetic group, as well as presenting a variation of chromosome number, ranging from $2 \mathrm{n}=34$ to 54 chromosomes, and the existence of simple and multiple sex chromosome system and the occurrence of chromosomal polymorphisms involving chromosomes that carry the nucleolus organizer region. In this study, a repetitive element by restriction enzyme, from Ancistrus sp.1 "Flecha" was isolated, which showed similarity with a transposable element Tc1-mariner. Its chromosomal location is distributed in heterochromatic regions and along the chromosomal arms of all specimens covered in this study, confirming the pattern dispersed of this element found in other studies carried out with other species. Thus, this result reinforces the hypothesis that the sequence AnDraI is really a dispersed element isolated. As this isolated sequence showed the same pattern in all species which have different sex chromosomes systems, including in all sex chromosomes, we could know that it is not involved in sex chromosome differentiation.
\end{abstract}

\section{Keywords}

Repetitive DNA, enzyme digestion, chromosomal mapping, transposable elements, in situ fluorescence hybridization 


\section{Introduction}

The genome of eukaryotes consists mostly of large amounts of repetitive DNA, which has been associated with several functions in the genome, as can be seen in the review carried out by Shapiro (2010). These functions range from important roles in the structure of chromosomes, the telomere and centromere maintenance mechanism (Pardue and Debaryshe 2003, Wong and Choo 2004), involvement in DNA replication process ( $\mathrm{Li}$ et al. 2002), of recombination (Biet et al. 1999) and gene expression (Liu et al. 2001, Peaston et al. 2004, Han and Boeke 2005, Volff 2006), in origin and evolution of sex and supernumerary chromosomes (Lyon 2000, Steinemann and Steinemann 2005, Parise-Maltempi et al. 2007), besides being used as important markers for cytogenetic studies of evolution, genome organization and identification of chromosomal rearrangements in several groups of organisms (Biémont and Vieira 2006, Martins 2007, Oliveira et al. 2013).

Basically, the repetitive sequences are represented by tandem repeats, as satellite DNA, minisatellite, and microsatellite repeats or dispersed along the DNA as retrotransposons and transposons (Charlesworth et al. 1994). The transposable elements (TEs) are classified according to the type of intermediate transposition, being of class I those that possess RNA intermediates and class II those whose intermediates are DNA molecules (Kidwell 2002). Transposons, belonging to Class II, representing most of the moderately repeated sequences of the eukaryotic genome, can be located in the region of constitutive heterochromatin and / or interspersed through the chromosomes and evolved through the ability to replicate making copies of themselves and moving to other regions of the genome (Capriglione et al. 2002).

When transposed, if the transposition occurs within promoter regions, introns or untranslated regions, it can affect the expression of this gene (Maksakova et al. 2006) and, although most of these mutations are harmful, the transposition of these elements have contributed to diversification of species due to generation of new alleles (Kapitonov and Jurka 2006). Its ability to spread in multiple copies may be regarded as a driving force for the evolution of the genome and, indeed seems to promote the variability of the genome, which may lead to a determination regulatory mutations and chromosomal rearrangements (Syvanen 1984, Charlesworth et al. 1994).

Based on the similarity between the sequences and phylogenetic analysis of the transposase, the transposable elements can be classified in ten families: Tc1/mariner, haT, P element, MuDR/Fokdback, Cacta, PiggyBac, Pif/Harbinger, Merlin, Transib and Banshee (Feschotte and Pritham 2007). Since the discovery of transposable elements in eukaryotes, elements such as Tc1 / mariner have been isolated from different fish species (Radice et al. 1994, Izsvák et al. 1995, Ivics et al. 1996, Capriglione et al. 2002, Krasnov et al. 2005, Pocwierz-Kotus et al. 2007, Liu et al. 2009).

This element, belonging to a superfamily of transposons, presents 1000 up to 2000 bp (Kidwell 2002), characterized by a simple structure with two inverted terminal repeats (TIRs) of approximately 28 bp. Also has an ORF (Opening Read Frame) encoding the transposase (Wallau et al. 2011) and is widely distributed among organisms, 
from protozoa to vertebrates. However, due to various events - mutations, deletions and insertions which become permanent component of the genome (Pocwierz et al. 2007), the majority is currently in an inactive form (Miskey et al. 2005).

The genus Ancistrus (Kner,1854) is one of the most diverse of tribe Ancistrinae, popularly known as "cascudos", and currently has 68 nominal species (Eschmeyer 2015). Its taxonomy is very confusing and a lot of species already have to be described. Based on chromosomal analysis, (Mariotto et al. 2011) suggested the existence of 13 cytotypes for the Ancistrus species found in the basis of rivers Paraguay, Araguaia-Tocantins and the Amazon in the Mato Grosso state (Brazil). They also suggested the existence of possible new species in this region, which show variation in chromosome number diploid ranging from $2 n=34$ to 54 chromosomes, presence of simple and multiple sex chromosome systems with both heterogametic sex and occurrence of chromosomal polymorphisms involving the chromosomes carrying the nucleolus organizing region for the group (Alves et al. 2003, Alves et al. 2006; Mariotto and Miyazawa 2006, Oliveira et al. 2007, Mariotto et al. 2009). Systems of ZZ/ZW and XX/XY sex chromosomes were found in populations of Ancistrus cf. dubius and Ancistrus sp 08 from the wetland of Mato Grosso state (Brazil) (Mariotto et al. 2004, Mariotto and Miyazawa 2006), the X0 system in Ancistrus n. sp.1 from "Rio Vermelho" located in Goiás state (Brazil) (Alves et al. 2006) and multiple systems of XX/XY1Y2 and Z1Z1Z2Z2/Z1Z2W1W2 for the species Ancistrus sp.1 "Balbina" and Ancistrus sp.2 "Barcelos" from Amazon state (Brazil) (De Oliveira et al. 2008).

Thus, taking into account the karyotype diversity of Ancistrus, including different sex chromosome systems, location of nucleolus organizer regions (NOR) and number of chromosomes, this study aimed to isolate repetitive sequences that could help in better understanding of the karyotype organization of the Ancistrus species.

\section{Material and methods}

\section{Samples}

The species of Ancistrus covered in this study were collected in the Flecha river, Creek Currupira, Pari and Sangradouro in the Paraguay river basin (Table 1). The collected material was taken to the Animal Genetics Laboratory at the Federal University of Mato Grosso, where 109 chromosome preparations were obtained.

\section{Preparation of mitotic chromosomes}

The chromosome preparations were made from the kidney of specimens collected following the methodology described by Foresti et al. (1993). The material was stored in a freezer at $-20{ }^{\circ} \mathrm{C}$. 
Table I. Collection site and number of species collected.

\begin{tabular}{|c|c|c|}
\hline Specie & Collection site & Number of collected species \\
\hline Ancistrus sp1 "Flecha" & $15^{\circ} 58^{\prime} 7^{\prime \prime S} 57^{\circ} 19^{\prime} 7 " \mathrm{~W}$ & $18 \mathrm{~F}-6 \mathrm{M}$ \\
\hline Ancistrus sp "Currupira" & 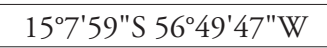 & $19 \mathrm{~F}-23 \mathrm{M}$ \\
\hline Ancistrus sp "Pari" & $15^{\circ} 36^{\prime} 6^{\prime \prime S ~} 56^{\circ} 12^{\prime} 19^{\prime \prime W}$ & $7 \mathrm{~F}-12 \mathrm{M}$ \\
\hline Ancistrus sp "Sangradouro" & $16^{\circ} 4^{\prime} 25^{\prime \prime S} 57^{\circ} 40^{\prime} 31.1^{\prime \prime W}$ & $5 \mathrm{~F}-4 \mathrm{M}$ \\
\hline
\end{tabular}

\section{Characterization of karyotypes}

C-bands were detected according to Sumner (1972) to assemble the karyotypes.

\section{Obtaining repetitive sequences}

The extraction of genomic DNA was performed from liver and fin of the specimens collected, basically following the protocol phenol / chloroform / isoamyl alcohol by Sambrook and Russel (2001). The extracted genomic DNA was digested with various restriction enzymes to isolation of repetitive sequences in a proportion of $30 \mu \mathrm{l}$ DNA (100 ng) in $3 \mu \mathrm{l}$ of enzyme. This solution was left at $37^{\circ} \mathrm{C}$ (temperature according to the enzyme used) overnight and after 7 hours of digestion was further added $3 \mu \mathrm{l}$ of enzyme. For precipitation and purification of the digested DNA $2 \mu \mathrm{l}$ of $5 \mathrm{M} \mathrm{NaCl}$ and $200 \mu \mathrm{L}$ of ice cold $100 \%$ ethanol was added. This solution was stored for two hours at $-80{ }^{\circ} \mathrm{C}$ and centrifuged after two hours. Digested DNA was eluted in $10 \mu \mathrm{l}$ of distilled water and analyzed in agarose gel $1 \%$ stored in the freezer for later use. The bands of potential repetitive sequences were then purified according the QIAquick PCR Purification Kit protocol (Qiagen). To perform the cloning, competent bacteria were prepared in the laboratory according to chemical transformation with $\mathrm{CaCl}_{2}$ (Mandel and Higa 1970). The DNA fragments were inserted into plasmid vectors with pMOS Blue Kit (Amersham Biosciences) following the manufacturer's specifications.

\section{DNA sequencing}

The amplified and purified DNA by treatment with ExoSAP enzyme (USB) was sequenced by the method of Sanger et al. (1977) through outsourcing of services by MacroGen company (Korea). The editing of the sequences was performed on the program BioEdit sequence alignment editor v7.0.5.3 (Hall 1999) using the Clustal W tool for performing alignment of the sequences. For the characterization of the tools sequences were used: BLAST - Basic Local Alignment Search Tool at National Center for Biotechnology Information (NCBI) website (http://www.ncbi.nlm.nih.gov/blast); 
CENSOR; RepeatMasker, website (http://www.repeatmasker.org/cgi-bin/WEBRepeatMasker) and ORF Finder, the National Center for Biotechnology Information (NCBI) website (http://www.ncbi.nlm.nih.gov/ gorf / gorf.html).

\section{DNA amplification via PCR}

The recombinant clones were subjected to PCR (Polymerase Chain Reaction) for amplification using the universal primers M13 F - GTA AAA CGA CGG CCA G and M13 R - CAG GAA ACA GCT ATG AC under the following conditions: denaturation at $95^{\circ} \mathrm{C}$ for 3 minutes, 34 cycles of denaturation at $95^{\circ} \mathrm{C}$ for 30 seconds, annealing at 50 for 1 minute, $72{ }^{\circ} \mathrm{C}$ extension for 2 minutes and elongation at $72{ }^{\circ} \mathrm{C}$ for 5 minutes.

After sequencing, the divergent primers were designed KD7116F - TCA CAA CAC ACG TTT GTG GA and KD7116R - AGA GCA GGC TTT GAA TCG G manually, which was synthesized by SIGMA company. Subsequently, the amplification of the sequence with the primer KD7116-1 also in other possible different species from other populations was performed following conditions: denaturation at 94 for 5 minutes, 30 cycles of denaturation at $94^{\circ} \mathrm{C}$ for 30 seconds, annealing at $58{ }^{\circ} \mathrm{C}$ for 1 minute $72{ }^{\circ} \mathrm{C}$ extension for $1 \mathrm{~min}$ and elongation at $72{ }^{\circ} \mathrm{C}$ for 7 minutes.

\section{Fluorescence in situ hybridization}

In situ hybridization was performed following the protocol by Pinkel et al. (1986) with some modifications. The fluorescent probes were labeled with digoxigenin by nick translation. The slides were mounted with antifading solution containing DAPI and chromosomes observed using an Olympus BX51 microscope and digital camera model D. The images were captured using the DP Controller software.

\section{Results}

\section{Karyotype analysis}

The analysis of constitutive heterochromatin by C-banding was performed to characterize all species karyotypes covered in this study. Ancistrus sp. 1 "Flecha" has $2 \mathrm{n}=44$ chromosomes and no heterochromatin block or sex chromosome system was shown (Fig. 1). Ancistrus sp. "Currupira" has $2 \mathrm{n}=44$ chromosomes and showed heterochromatin mainly at pericentromeric regions and a block in pair 13 (Fig. 2A), Ancistrus sp. "Pari" has $2 \mathrm{n}=42$ chromosomes with heterochromatin along pericentromeric regions and a block in pair 15 (Fig. 2B) and Ancistrus sp. "Sangradouro" has 2n=42 chromosomes, a karyotype similar to Ancistrus sp. "Pari" but its heterochromatin block is in pair 6 (Fig. 2C). 


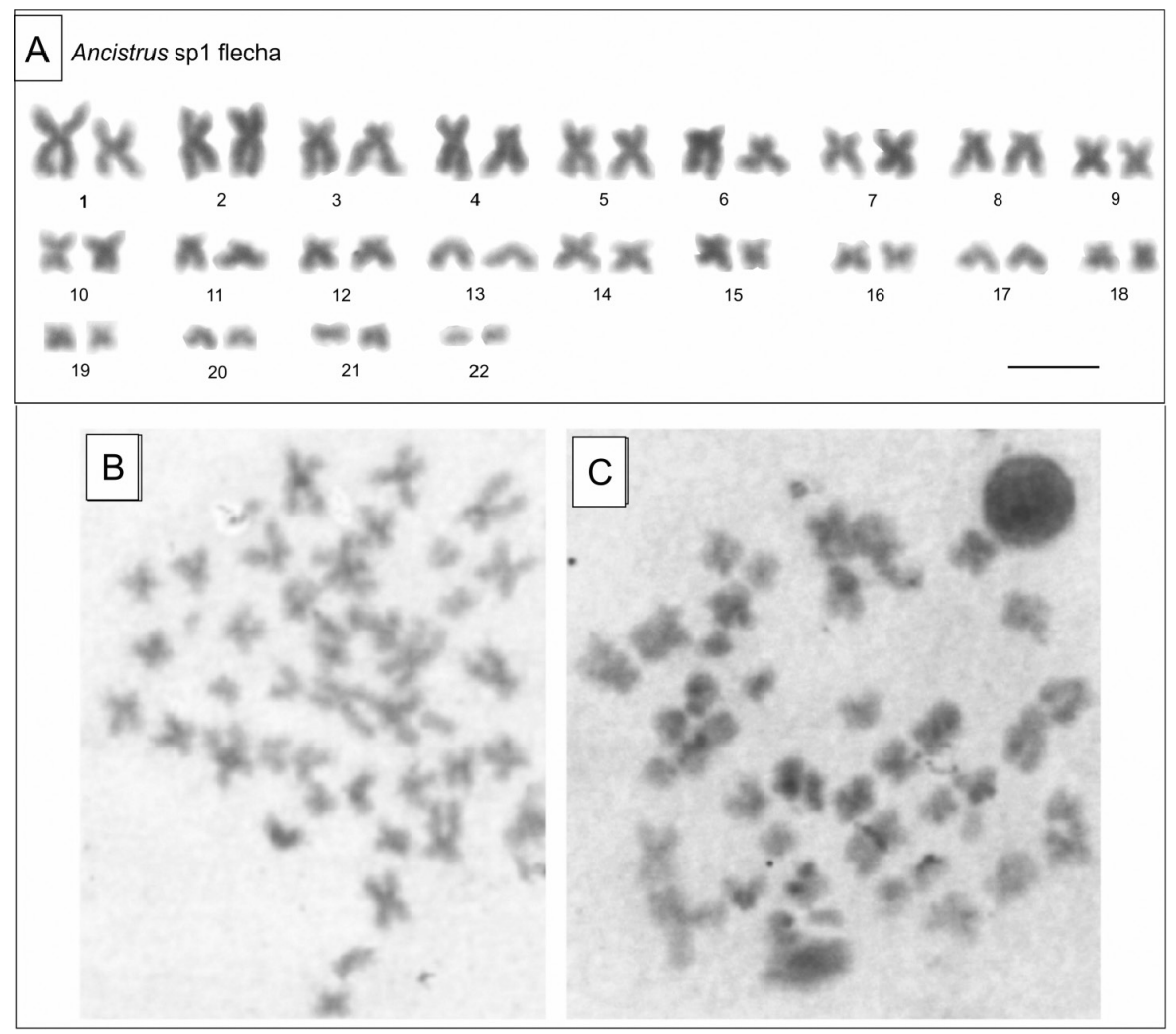

Figure I. Karyotype of Ancistrus sp.1 "Flecha" using C-banding. A Conventional staining- showing the karyotype of Ancistrus sp. 1 "Flecha" with $2 \mathrm{n}=44$ chromosomes, including a pair of microchromosomes B, $\mathbf{C}$ is C-band showing that the chromosomes of Ancistrus is not rich in heterochromatic regions in female and male. Bar $=10 \mu \mathrm{m}$.

\section{Analysis of AnDraI sequence}

After isolation of repetitive sequences with restriction enzymes using Ancistrus sp.1 "Flecha" DNA, it was possible to observe the formation of a band of approximately $700 \mathrm{bp}$. The product from this band was then cloned, resulting in 34 recombinant clones, from which one, named AnDraI was used in this study. The sequence of this clone had 618 bp and $44.34 \%$ of GC base pair. According with the databases consulted: Blast 2.0 RepeatMasker and Censor, the sequence obtained showed greater than $86 \%$ identity with the type of transposon Mariner/Tc1 of Xenopus tropicalis (Gray, 1864). In the analysis performed for possible coding regions, an ORF region of frame 3+ 188 bp (87-275) was found. As conserved domain, a region of approximately 180 nucleotides which corresponds to HTH_Tnp_Tc3_2_Transposase was found. By submitting this sequence in the protein data bank (Blastx), similarities were found with transposases of several species, including, Rana pipiens (Schreber, 1782), Xenopus tropicalis, Dicentrarchus labrax (Linnaeus, 1758), Salmo salar (Linnaeus, 1758), and Cyprinus carpio (Linnaeus, 1758) (Fig. 3). 


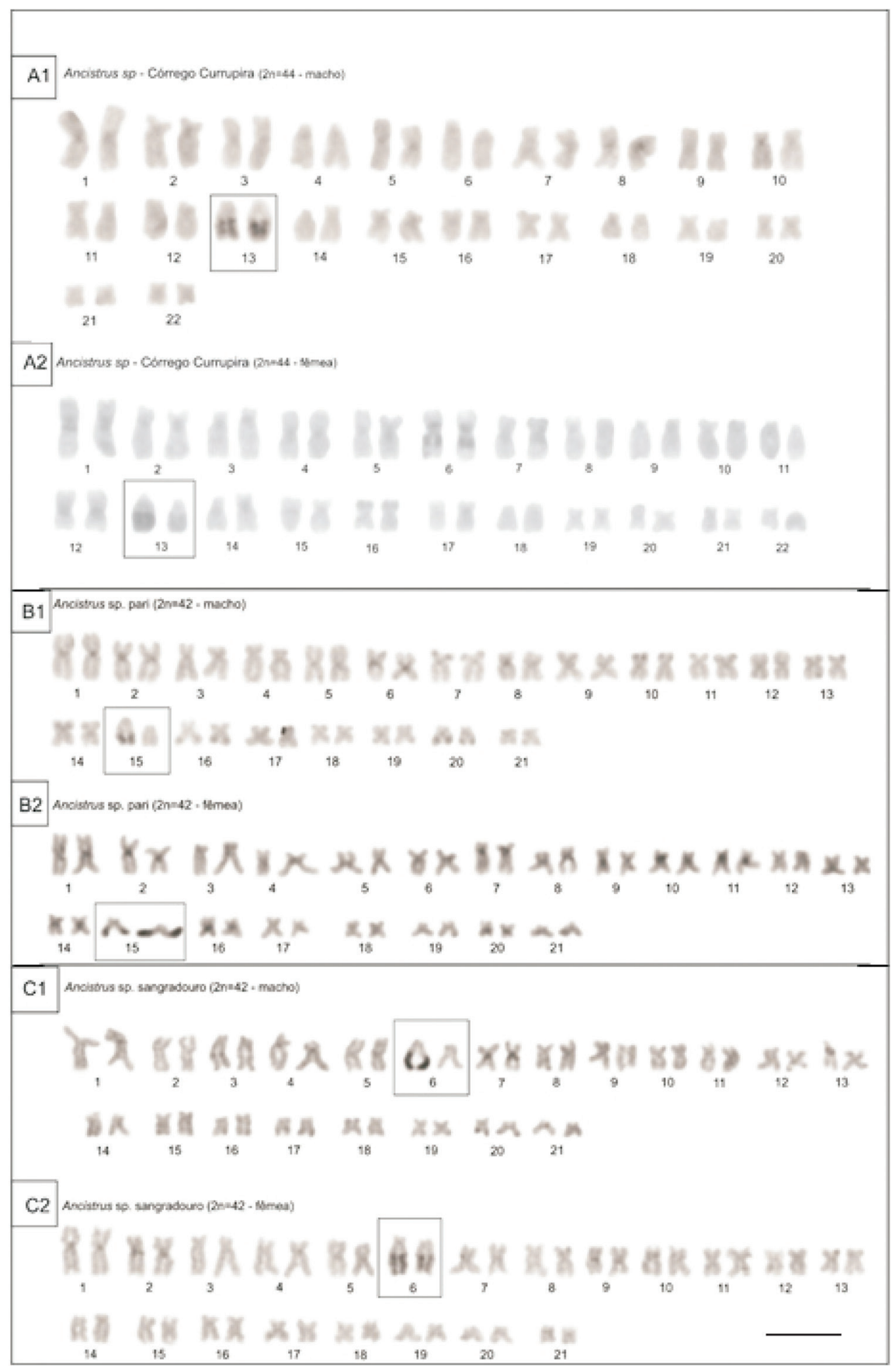

Figure 2. Karyotype after $\mathrm{C}$ band. Ancistrus sp. "Currupira" has $2 \mathrm{n}=44$ chromosomes and showed heterochromatin blocks mainly at centromeric regions and pair 13 (A), Ancistrus sp. "Pari" has $2 \mathrm{n}=42$ chromosomes with heterochromatin blocks along centromeric regions and a big block in pair 15 (B) and Ancistrus sp. "Sangradouro" has $2 \mathrm{n}=42$ chromosomes, a karyotype similar to Ancistrus sp. "Pari" but the big heterochromatin block is in pair $6(\mathbf{C})$. Bar $=10 \mu \mathrm{m}$. 


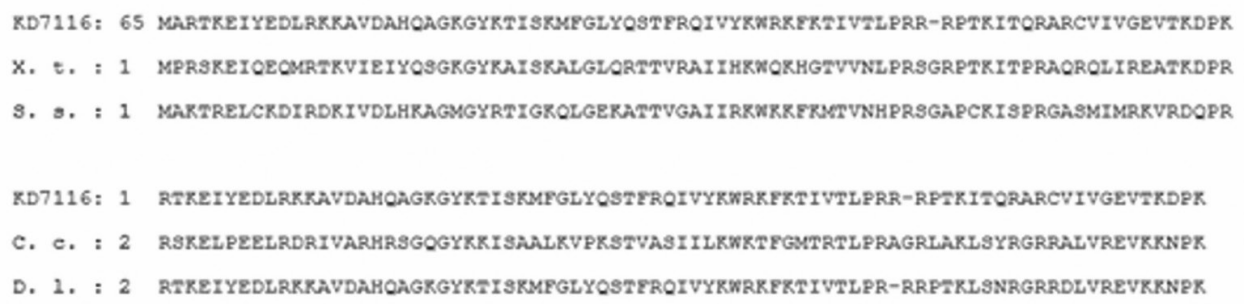

Figure 3. Comparison of the amino acid sequence of Transposase expected of AnDraI with Tc1-like transposase of other species. X. t. Xenopus tropicalis S. s. Salmo salar C. c. Cyprinus carpio D. I. Dicentrarchus labrax.

\section{PCR analysis of the sequence Tc1-like in specimens from other populations}

It was realized an amplification of AnDraI element by polymerase chain reaction in the genome of other specimens of other populations: Ancistrus sp. "Currupira" from Currupira Creek, Ancistrus sp. "Pari" from Pari Creek and Ancistrus sp. "Sangradouro" from Sangradouro Creek. Both, males and females, of this species showed the same length of fragments (not shown).

\section{Chromosomal mapping of the transposon}

Chromosomal in situ hybridization performed on Ancistrus sp.1 "Flecha" revealed signals throughout all the chromosomes preferentially located in pericentromeric regions, with no difference between males and females (Fig. 4).

Cross-Fish conducted in individuals from other localities also showed results similar to that found in Ancistrus sp.1 "Flecha" (Fig. 5).

\section{Discussion}

The transposable element Tc1, first identified in invertebrates as Caenorhabditis elegans (Maupas, 1900), have around $1600 \mathrm{bp}$ and share similar structures, known as Terminal inversed regions (TIRs) that show a sequence of 5 to $6 \mathrm{bp}$ identical in/or near the highly conserved ends (CAGTG/CAGTC) (Brezinsky et al. 1990, Avancini et al. 1996). However, there is a great variation between the number of copies, distribution and types of transposable elements, between different species arising from factors such as intrinsic characteristics of the transposable elements (TEs) and the different evolutionary forces that act on these (Capy et al. 1998).

The Tc1-like element isolated in this work from Ancistrus sp.1 "Flecha" appears to share a very similar structure to TcMar-Tc1 of Xenopus (Siluriana) tropicalis, which is $532 \mathrm{bp}$, equivalent to $86.1 \%$. This element appears widely distributed throughout all 

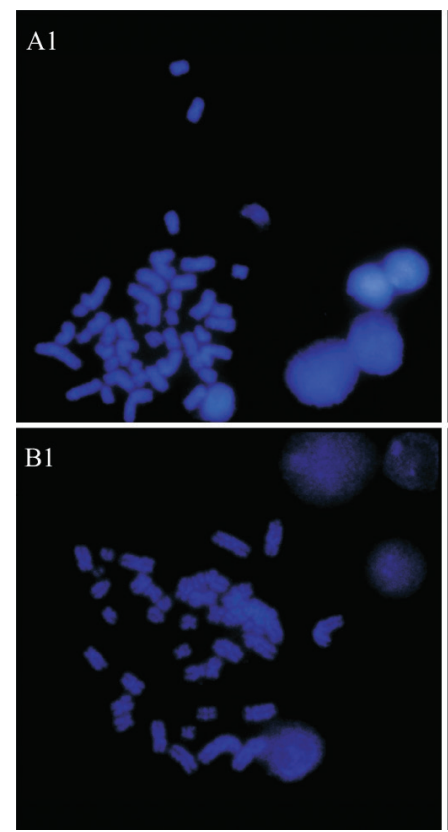
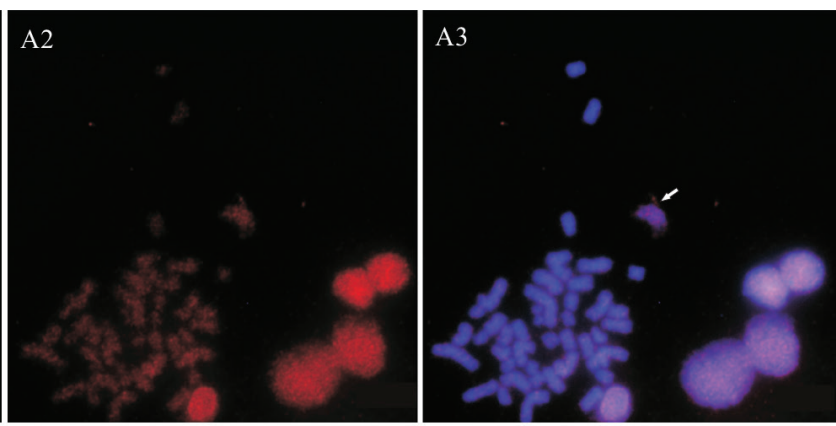

B2

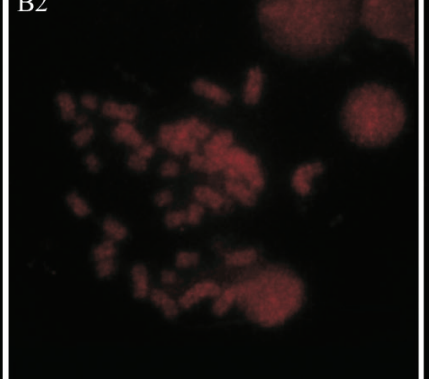

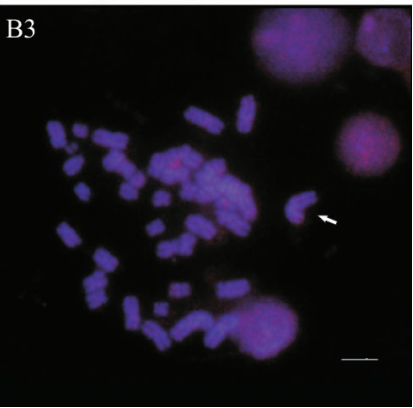

Figure 4. In situ fluorescence hybridization using AnDraI as probe in Ancistrus sp.1 "Flecha": A female B male. The arrows show some examples of pericentromeric and spread signals. Bar $=10 \mu \mathrm{m}$.

the chromosomes of all specimens of Ancistrus covered in this study, with some specific concentrations in pericentromeric regions. These specimens belong to distinct localities with a high geographic distance and isolated among themselves, with different karyotypes which show number chromosomes ranging from $2 n=42$ to 44 and species with no sex chromosomes system and others with XX/XY or ZZ/ZW sex chromosomes. Despite of the known cytogenetic differences among the Ancistrus group it can be said that, at least among the specimens analyzed, the AnDral element presents the same homogeneous pattern of distribution and no correlation can be made regarding the karyotypes differences neither the origin and differentiation of sex chromosomes of this group involving its isolated sequence. However, it can be inferred that, despite the low number of populations analyzed it is possible to consider that the AnDra I element is present in the genome of the Ancistrus genus. Although the Siluriformes group have a scientific and economic importance, their systematic and taxonomy are still highly problematic and, in this context, studies involving repetitive sequences, which are showed to be important cytogenetic markers, may help uncover the evolutionary history of the group.

Repetitive sequences may be present in centromeres and telomeres of eukaryotic chromosomes which are rich regions in heterochromatin, as well as regions over the interstitial chromosomal arms (Csink and Henikoff 1998). The in situ hybridization experiments in the chromosomes of Ancistrus sp. showed that the Tc1-like element is located throughout all the chromosomes with preferential markings in heterochro- 

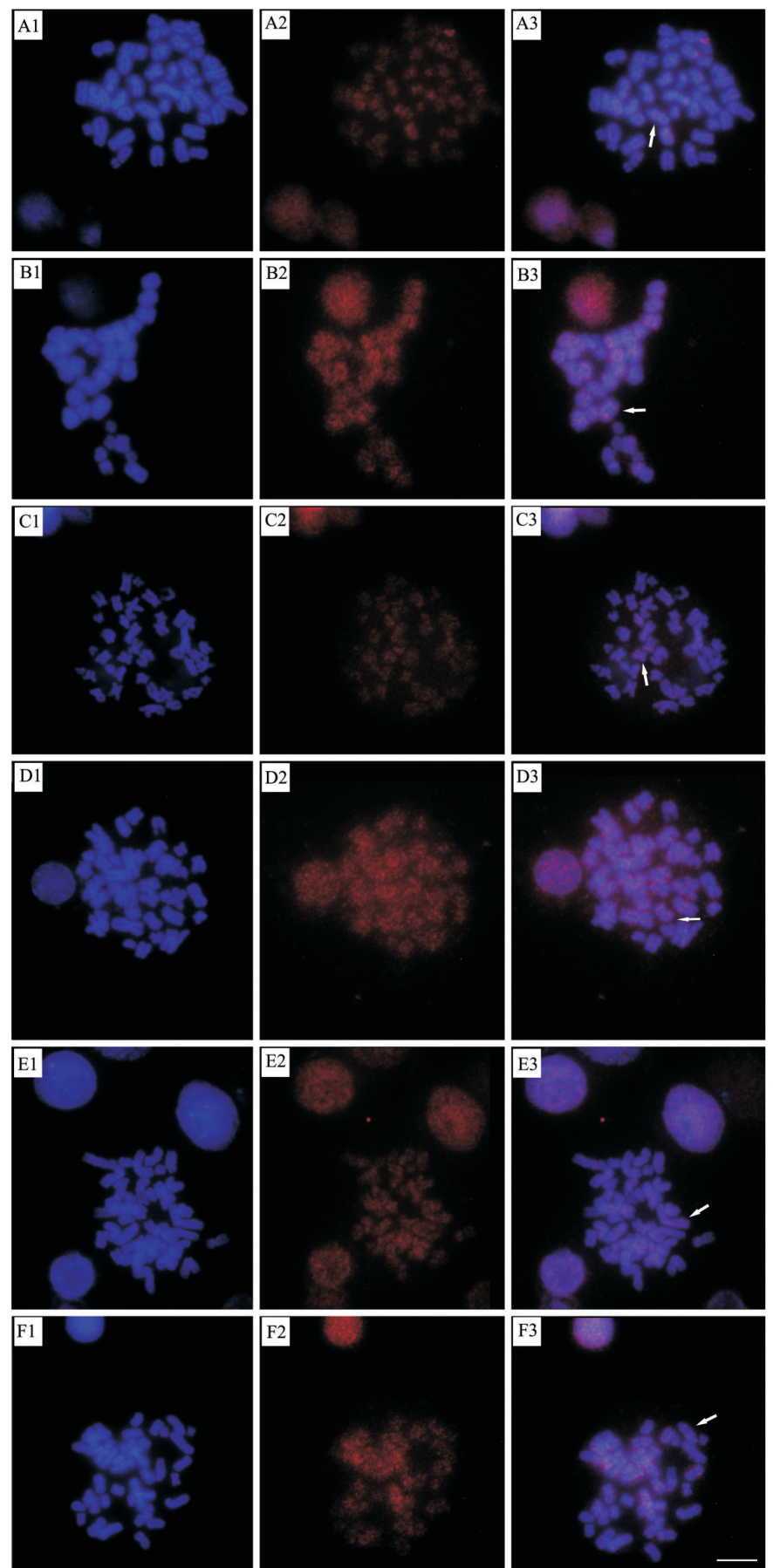

Figure 5. In situ fluorescence hybridization using AnDraI as probe in Ancistrus chromosomes: A Female of Currupira creek B Male of Currupira creek C Female of Pari creek D Male of Pari creek E Female of Sangradouro creek e $\mathbf{F}$ Male of Sangradouro creek. The arrows show some examples of pericentromeric and spread signals. Bar $=10 \mu \mathrm{m}$. 
matic regions along the chromosomal arms, corroborating the results found in other studies carried out in other fish species, evidencing a pattern to disperse these elements (Capriglione et al. 2002, Ozouf-Costaz et al. 2004, Schemberger et al. 2014).

Results found in the literature about the genomic organization of transposons suggest that these elements are differently distributed in distinct groups of fish (Ferreira et al. 2011), as for example in the Oreochromis niloticus (Linnaeus, 1758) (Charlesworth et al. 1994, Martins 2007, Oliveira et al. 2013), Antartic Perciformes (Ozouf-Costaz et al. 2004) and in species of the subfamily Hypoptopomatinae (Dasilva et al. 2002), in which these elements can be found scattered throughout the genome. However, in species such as Tetraodon nigroviridis (Marion de Procé, 1822) (Dasilva et al. 2002, Fischer et al. 2004) and in most of the species of Cichlidae (Gross et al. 2009, Valente et al. 2011) they can be found accumulated in chromosomal regions rich in constitutive heterochromatin. Among the Siluriformes, the elements Rex1 and Rex3, in Hisonotus leucofrenatu (Ribeiro, 1908), Pseudotocinclus tietensis (Ihering, 1907) and Parotocinclus maculicauda (Steindachner, 1877), presented dispersed distributions patterns in the genome, similar to the pattern found for the transposable element AnDraI (Ferreira et al. 2011a), as well as a new dispersed element, BamHI, isolated by Ferreira et al. (2011b), in the genome of Hisonotus leucofrenatus. The genomic organization result of the Tc1like element obtained in this work reinforces the hypothesis that the sequence AnDraI isolated is a dispersed element, and reinforces the hypothesis proposed by Ferreira et al. (2011) in which all transposable elements behave similarly inside of a family or subfamily. Also the study and characterization of these sequences can start to help to understand the evolutionary dynamics of Ancistrus genome, as well as the great karyotypic and chromosomal variability of this group, especially in the Paraguay river basin.

\section{References}

Alves AL, Oliveira C, Foresti F (2003) Karyotype variability in eight species of the subfamilies Loricariinae and Ancistrinae (Teleostei, Siluriformes, Loricariidae). Caryologia 56(1): 57-63. https://doi.org/10.1080/00087114.2003.10589308

Alves AL, Oliveira C, Nirchio M, Granado Á, Foresti F (2006) Karyotypic relationships among the tribes of Hypostominae (Siluriformes: Loricariidae) with description of XO sex chromosome system in a Neotropical fish species. Genetica 128(1-3): 1-9. https://doi. org/10.1007/s10709-005-0715-1

Avancini RMP, Walden KKO, Robertson HM (1996) The genomes of most animals have multiple members of the Tc1 family of transposable elements. Genetica 98(2): 131-140. https://doi.org/10.1007/BF00121361

Bièmont C, Vieira C (2006) Junk DNA as an evolutionary force. Genetics 443(7111): 521-524. https://doi.org/10.1038/443521a

Biet E, Sun JS, Dutreix M (1999) Conserved sequence preference in DNA binding among recombination proteins: an effect of ssDNA secondary structure. Nucleic Acids Research 27(2): 596-600. https://doi.org/10.1002/bies.20452 
Brezinsky L, Wang GVL, Humphreys T, Hunt J (1990) The transposable element Uhu from Hawaiian Drosophila-member of the widely dispersed class of Tc1-like transposons. Nucleic Acids Research 18(8): 2053-2059. https://doi.org/10.1093/nar/18.8.2053

Capriglione T, Odierna G, Caputo V, Canapa A, Olmo E (2002) Characterization of a Tc1like transposon in the Antarctic ice-fish, Chionodraco hamatus. Gene 295(2): 193-198. https://doi.org/10.1016/S0378-1119(02)00729-1

Capy P, Langin T, Ansolabehere D, Bazin C (1998) Dynamics and evolution of transposable elements. In: Thomson Learning (Eds) Molecular Biology Intelligence Unit, 197 pp. https://doi.org/10.1590/S1415-47572005000500024

Charlesworth B, Sniegowski P, Stephan W (1994) The Evolutionary Dynamics of Repetitive DNA in Eukaryotes. Nature 371(6494): 215-220. https://doi.org/10.1038/371215a0

Csink AK, Henikoff S (1998) Something from Nothing: The Evolution and Utility of Satellite Repeats. Trends in Genetics 14(5): 200-204. https://doi.org/10.1016/S0168-9525(98)01444-9

Dasilva C, Hadji H, Ozouf-Costaz C, Nicaud S, Jaillon O, Weissenbach J, Crollius HR (2002) Remarkable compartmentalization of transposable elements and pseudogenes in the heterochromatin of the Tetraodon nigroviridis genome. Proceedings of the National Academy of Sciences 99(21): 13636-13641. https://doi.org/10.1073/pnas.202284199

De Oliveira RR, Feldberg E, Dos Anjos MB, Zuanon J (2008) Occurrence of multiple sexual chromosomes (XX/XY1Y2 and Z1Z1Z2Z2/Z1Z2W1W2) in catfishes of the genus Ancistrus (Siluriformes: Loricariidae) from the Amazon basin. Genetica 134(2): 243-249. https://doi.org/10.1007/s10709-007-9231-9

Eschmeyer W (2015) Catalog of Fishes: GENERA, SPECIES, REFERENCES http://www. calacademy.org/scientists/projects/catalog-of-fishes [accessed 10. february 2016]

Ferreira DC, Oliveira C, Foresti F (2011a) Chromosome Mapping of Retrotransposable Elements Rex1 and Rex3 in Three Fish Species in the Subfamily Hypoptopomatinae (Teleostei, Siluriformes, Loricariidae). Cytogenetic and Genome Research 132(1-2): 64-70. https://doi.org/10.1159/000319620

Ferreira DC, Oliveira C, Foresti F (2011b) A new dispersed element in the genome of the catfish Hisonotus leucofrenatus (Teleostei: Siluriformes: Hypoptopomatinae). Mobile Genetic Elements 1(2): 103-106. https://doi.org/10.4161/mge.1.2.17450

Ferreira DC, Porto-Foresti F, Oliveira C, Foresti F (2011) Transposable elements as a potential source for understanding the fish genome. Mobile Genetic Elements 1(2): 112-117. https://doi.org/10.4161/mge.1.2.16731

Feschotte C, Pritham EJ (2007) DNA Transposons and the Evolution of Eukaryotic Genomes. Annual Review of Genetics 41(1): 331-368. https://doi.org/10.1146/annurev. genet.40.110405.090448

Fischer C, Bouneau L, Coutanceau JP, Weissenbach J, Volff JN, Ozouf-Costaz C (2004) Global heterochromatic colocalization of transposable elements with minisatellites in the compact genome of the pufferfish Tetraodon nigroviridis. Gene 336(2): 175-183. https:// doi.org/10.1016/j.gene.2004.04.014

Foresti F, Oliveira C, Almeida-Toledo LF (1993) A method for chromosome preparations from large fish specimens using in vitro short-term treatment with colchicine. Experientia 49(9): 810-813. https://doi.org/10.1007/BF01923555 
Gross MC, Schneider CH, Valente GT, Porto JIR, Martins C, Feldberg E (2009) Comparative Cytogenetic Analysis of the Genus Symphysodon (Discus Fishes, Cichlidae): Chromosomal Characteristics of Retrotransposons and Minor Ribosomal DNA. Cytogenetic and Genome Research 127(1): 43-53. https://doi.org/10.1159/000279443

Hall TA (1999) BioEdit: a user-friendly biological sequence alignment editor and analysis program for Windows 95/98/NT. Nucleic Acids 41: 95-98.

Han JS, Boeke JD (2005) LINE-1 retrotransposons: Modulators of quantity and quality of mammalian gene expression? BioEssays 27(8): 775-784. https://doi.org/10.1002/bies.20257

Ivics Z, Izsvak Z, Minter A, Hackett PB (1996) Identification of functional domains and evolution of Tc1-like transposable elements. Proceedings of the National Academy of Sciences 93(10): 5008-5013. https://doi.org/10.1073/pnas.93.10.5008

Izsvák Z, Ivics Z, Hackett PB (1995) Characterization of a Tc1-like transposable element in zebrafish (Danio rerio). Molecular \& general genetics: MGG 247(3): 312-322. https://doi. org/10.1016/j.ymthe.2003.11.024

Kapitonov VV, Jurka J (2006) Self-synthesizing DNA transposons in eukaryotes. Proceedings of the National Academy of Sciences 103(12): 4540-4545. https://doi.org/10.1073/ pnas.0600833103

Kidwell MG (2002) Transposable elements and the evolution of genome size in eukaryotes. Genetica 115(1): 49-63. https://doi.org/10.1023/A:1016072014259

Krasnov A, Koskinen H, Afanasyev S, Molsa H (2005) Transcribed Tc1-like transposons in salmonid fish. BMC Genomics 6(1): 107. https://doi.org/10.1186/1471-2164-6-107

Li YC, Korol AB, Fahima T, Beiles A, Nevo E (2002) Microsatellites: genomic distribution, putative functions and mutational mechanisms: a review. Molecular Ecology 11(12): 2453-2465. https://doi.org/10.1046/j.1365-294X.2002.01643.x

Liu D, You C, Liu S, Liu L, Duan W, Chen S, Yan J, Liu Y (2009) Characterization of a Novel Tc1-Like Transposon From Bream (Cyprinidae, Megalobrama) and Its Genetic Variation in the Polyploidy Progeny of Bream-Red Crucian Carp Crosses. Journal of Molecular Evolution 69(4): 395-403. https://doi.org/10.1007/s00239-009-9295-5

Liu Z, Li P, Kocabas A, Karsi A, Ju Z (2001) Microsatellite-Containing Genes from the Channel Catfish Brain: Evidence of Trinucleotide Repeat Expansion in the Coding Region of Nucleotide Excision Repair Gene RAD23B. Biochemical and Biophysical Research Communications 289(2): 317-324. https://doi.org/10.1006/bbrc.2001.5978

Lyon MF (2000) LINE-1 elements and X chromosome inactivation: A function for "junk" DNA? Proceedings of the National Academy of Sciences 97(12): 6248-6249. https://doi. org/10.1073/pnas.97.12.6248

Maksakova IA, Romanish MT, Gagnier L, Dunn CA, Van De Lagemaat LN, Mager DL (2006) Retroviral elements and their hosts: insertional mutagenesis in the mouse germ line. PLoS genetics 2(1): e2. https://doi.org/10.1371/journal.pgen.0020002

Mandel M, Higa A (1970) Calcium-dependent bacteriophage DNA infection. Journal Molecular Biology 53: 159-162. https://doi.org/10.1016/0022-2836(70)90051-3

Mariotto S, Artoni RF, Miyazawa CS (2004) Occurrence of sexual chromosome, of the type ZZ/ ZW, in Ancistrus cf. dubius (Loricariidae, Ancistrinae) of the Paraguay River Basin, Mato Grosso, Brazil. Caryologia 57(4): 327-331. https://doi.org/10.1080/00087114.2004.10589413 
Mariotto S, Centofante L, Miyazawa CS, Bertollo LAC, Moreira Filho O (2009) Chromosome polymorphism in Ancistrus cuiabae Knaack, 1999 (Siluriformes: Loricariidae: Ancistrini). Neotropical Ichthyology 7(4): 595-600. https://doi.org/10.1590/S167962252009000400006

Mariotto S, Centofante L, Vicari M, Artoni R, Moreira Filho O (2011) Chromosomal diversification in ribosomal DNA sites in Ancistrus Kner, 1854 (Loricariidae, Ancistrini) from three hydrographic basins of Mato Grosso, Brazil. Comparative Cytogenetics 5(4): 289-300. https://doi.org/10.3897/compcytogen.v5i4.1757

Mariotto S, Miyazawa CS (2006) Ancistrus cf. dubius (Siluriformes, Ancistrinae), a complex of species. 1. Chromosomic characterization of four populations and occurence of sexual chromosomes of type XX/XY, in the pantanal basin of Mato Grosso, Brazil. Caryologia 59(4): 299-304. https://doi.org/10.1080/00087114.2006.10797929

Martins C (2007) Chromosomes and repetitive DNAs: a contribution to the knowledge of fish genome. In: Pisano E, Ozouf-Costaz C, Foresti F, Kapoor BG (Eds) Fish Cytogenetics. Science, 421-453. https://books.google.com.br/books?id=YZY6AQAAQBAJ\&dq

Miskey C, Izsvàk Z, Kawakami K, Ivics Z (2005) DNA transposons in vertebrate functional genomics. Cellular and Molecular Life Sciences 62(6): 629-641. https://doi.org/10.1007/ s00018-004-4232-7

Oliveira RR, Feldberg E, Anjos MB, Zuanon J (2007) Karyotype characterization and ZZ/ ZW sex chromosome heteromorphism in two species of the catfish genus Ancistrus Kner, 1854 (Siluriformes: Loricariidae) from the Amazon basin. Neotropical Ichthyology 5(3): 301-306. https://doi.org/10.1590/S1679-62252007000300010

Oliveira SG, Cabral-De-Mello DC, Moura RC, Martins C (2013) Chromosomal organization and evolutionary history of Mariner transposable elements in Scarabaeinae coleopterans. Molecular Cytogenetics 6(1): 54. https://doi.org/10.1186/1755-8166-6-54

Ozouf-Costaz C, Brandt J, Korting C, Pisano E, Bonillo C, Coutanceau JP, Volff JN (2004) Genome dynamics and chromosomal localization of the non-LTR retrotransposons Rex1 and Rex3 in Antarctic fish. Antarctic Science 16(1): 51-57. https://doi.org/10.1017/ S0954102004001816

Pardue ML, Debaryshe PG (2003) Retrotransposons Provide an Evolutionarily Robust NonTelomerase Mechanism to Maintain Telomeres. Annual Review of Genetics 37(1): 485-511. https://doi.org/10.1146/annurev.genet.38.072902.093115

Parise-Maltempi PP, Martins C, Oliveira C, Foresti F (2007) Identification of a new repetitive element in the sex chromosomes of Leporinus elongatus (Teleostei: Characiformes: Anostomidae): new insights into the sex chromosomes of Leporinus. Cytogenetic and Genome Research 116(3): 218-223. https://doi.org/10.1159/000098190

Peaston AE, Evsikov AV, Graber JH, De Vries WN, Holbrook AE, Solter D, Knowles BB (2004) Retrotransposons regulate host genes in mouse oocytes and preimplantation embryos. Developmental Cell 7(4): 597-606. https://doi.org/10.1016/j.devcel.2004.09.004

Pinkel D, Straume T, Gray JW (1986) Cytogenetic analysis using quantitative, high-sensitivity, fluorescence hybridization. Proceedings of the National Academy of Sciences of the United States of America 83(9): 2934-2938. https://doi.org/10.1073/pnas.83.9.2934 
Pocwierz-Kotus A, Burzynski A, Wenne R (2007) Family of Tc1-like elements from fish genomes and horizontal transfer. Gene 390(1-2): 243-251. https://doi.org/10.1016/j. gene.2006.10.020

Radice AD, Bugaj B, Fitch DH, Emmons SW (1994) Widespread occurrence of the Tc1 transposon family: Tc1-like transposons from teleost fish. Molecular \& general genetics: MGG 244(6): 606-612. https://doi.org/10.1007/BF00282750

Sambrook J, Russel MG (2001) Molecular cloning: a laboratory manual. Cold Spring Harbor Laboratory Press. http://www.cshlpress.com/pdf/sample/2013/MC4/MC4FM.pdf [accessed 10. february 2016]

Sanger F, Nicklen S, Coulson AR (1977) DNA sequencing with chain-terminating inhibitors. Proceedings of the National Academy of Sciences of the United States of America 74(12): 5463-5467. https://doi.org/10.1073/pnas.74.12.5463

Schemberger MO, Oliveira JIN, Nogaroto V, Almeida MC, Artoni RF, Cestari MM, Moreira-Filho O, Vicari MR (2014) Construction and Characterization of a Repetitive DNA Library in Parodontidae (Actinopterygii: Characiformes): A Genomic and Evolutionary Approach to the Degeneration of the W Sex Chromosome. Zebrafish 11(6): 518-527. https://doi.org/10.1089/zeb.2014.1013

Shapiro JA (2010) Mobile DNA and evolution in the 21st century. Mobile DNA 1(1): 4. https://doi.org/10.1186/1759-8753-1-4

Steinemann S, Steinemann M (2005) Retroelements: tools for sex chromosome evolution. Cytogenetic and Genome Research 110(1-4): 134-143. https://doi.org/10.1159/000084945

Sumner AT (1972) A simple technique for demonstrating centromeric heterochromatin. Experimental Cell Research 75(1): 304-306. https://doi.org/10.1016/0014-4827(72)90558-7

Syvanen M (1984) The evolutionary implications of mobile genetic elements. Annual Review of Genetics 18: 271-293 https://doi.org/10.1146/annurev.ge.18.120184.001415

Valente GT, Mazzuchelli J, Ferreira IA, Poletto AB, Fantinatti BEA, Martins C (2011) Cytogenetic Mapping of the Retroelements Rex1, Rex3 and Rex6 among Cichlid Fish: New Insights on the Chromosomal Distribution of Transposable Elements. Cytogenetic and Genome Research 133(1): 34-42. https://doi.org/10.1159/000322888

Volff JN (2006) Turning junk into gold: domestication of transposable elements and the creation of new genes in eukaryotes. BioEssays 28(9): 913-922 https://doi.org/10.1002/ bies. 20452

Wallau GL, Hua-Van A, Capy P, Loreto ELS (2011) The evolutionary history of mariner-like elements in Neotropical drosophilids. Genetica 139(3): 327-338 https://doi.org/10.1007/ s10709-011-9552-6

Wong LH, Choo KHA (2004) Evolutionary dynamics of transposable elements at the centromere. Trends in Genetics 20(12): 611-616 https://doi.org/10.1016/j.tig.2004.09.011 